\title{
Identification of zones of increased permeability using numerical modelling of temperature distribution - an ISMOP case study
}

\author{
Maciej Dwornik*, Anna Franczyk and Andrzej Leśniak \\ AGH University of Science and Technology, Faculty of Geology, Geophysics and Environmental \\ Protection, Kraków, Poland
}

\begin{abstract}
The physical condition of earthen levees changes over time. Levee weakening can be caused by the leaching of fine grains of soil or by animal activity. Weakened areas can potentially cause destabilization or even collapse. Assessment of the physical condition of levees using GPR and geodetic measurements does not always correctly detect areas of increased permeability.

Thermal anomalies, caused by existing zones of high permeability, are observed in levees during the transition of flood waves. They are generated by rapid infiltration of water with a different temperature than the temperature inside the levee. Therefore, inner thermal measurements may be used to detect places with higher permeability. This research was realized with 2D numerical modelling. Main aim was test possibility of using temperature sensors in weak zone detection. Test with different theoretical permeabilities proved that it is possible only in specific condition (i.e. thermal contrast). The geometry and geomechanical properties of the studied levee were taken from the ISMOP project (polish acronym: Computer system for monitoring river embankments).
\end{abstract}

Keywords: levee, temperature measurements, weakened area, numerical modelling

\section{Introduction}

Earthen levees are one of the most popular methods of protecting human life and properties against floods; however, they must be in good condition in order to offer proper protection. There are many methods of checking the condition of levees. These methods are mainly based on cyclic measurements in parts of levees (i.e. GPR [1], ERT [2], geodetic measurements). The long-time gaps between measurements mean that new weak zones are often not detected before floods.

There are only a few approaches to continuously monitoring large parts of levees [3-5]. There were mainly used water pore pressure sensors to recognize faster flows inside levee. The main problem is the huge length of these constructions, which is problematic when it is

\footnotetext{
* Corresponding author: dwornik@geol.agh.edu.pl
} 
considered that predictive systems should cheaply and easily determine any weak zones. One option is to use a dense grid of temperature sensors inside levees. This idea is based on two phenomena: thermal property differences between dry and wet soil, and larger zones of temperature changes if water whose temperature is different than the soil temperature infiltrates weak zones. So, if there is a temperature contrast between soil and water, it should be possible to determine weak zones by comparing neighbouring sensors.

In this paper, the idea of temperature sensors will be tested. Main aim was recognize possibility and restrictions of temperature sensors in detection weak zone. Thermal sensors were used previously, for example in monitoring roadway embankments [6]. Twodimensional numerical modelling is used to determine the temperature distribution inside a levee during a flood. The modelling is performed with parameters used in polish acronym: Computer System for Monitoring River Embankments (ISMOP) projects (flood wave shape, soil properties, weather conditions, levee geometry) [7].

The location of the weak zone is similar to the location of the buried pipe in the levee. A leaking zone appeared along this pipe during the conducted experiments. Different theoretical permeabilities of the weak zone and the temperature condition were also used in the numerical models.

\section{ISMOP Project}

The ISMOP (a Polish acronym) Project was carried out by AGH University of Science and Technology and two companies (Neosentio and Budokop), and co-funded by the National Centre of Research and Development. A full-size levee was built for tests and experiments (fig. 1). The levee has a stadium shape with a water reservoir inside. Different parts of the levee are constructed of a variety of materials and the slopes are similar to the levees found on Polish rivers. Several sensor networks were located inside the levee: six sections with 56 temperature and pore pressure sensors, 74 sections of 14 temperature sensors, two loops of optical fibre with temperature sensors with a $1 \mathrm{~m}$ offset along the fibre, 6 strain sensors and 33 piezometers (fig. 2) [8]. Additionally, GPR, ERT and LIDAR measurements were conducted periodically. Flood waves were simulated by changing the water level in the reservoir.

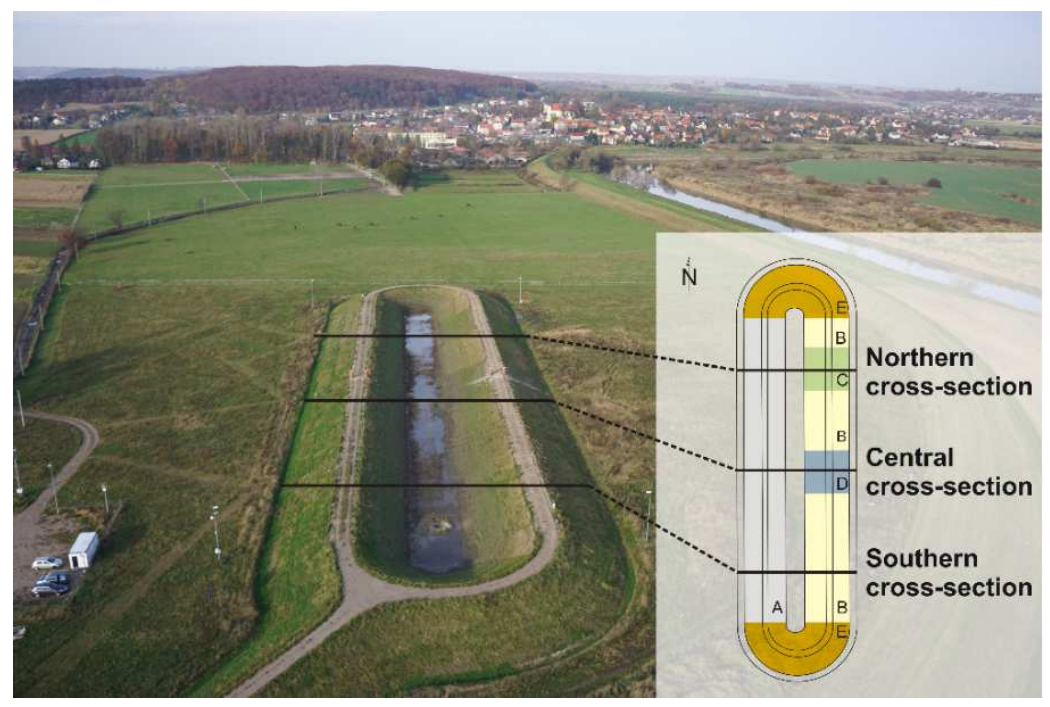

Fig. 1. Earthen construction built for the ISMOP Project ( $200 \times 50 \times 4.5 \mathrm{~m})$. A-E: type of material used [9]. 


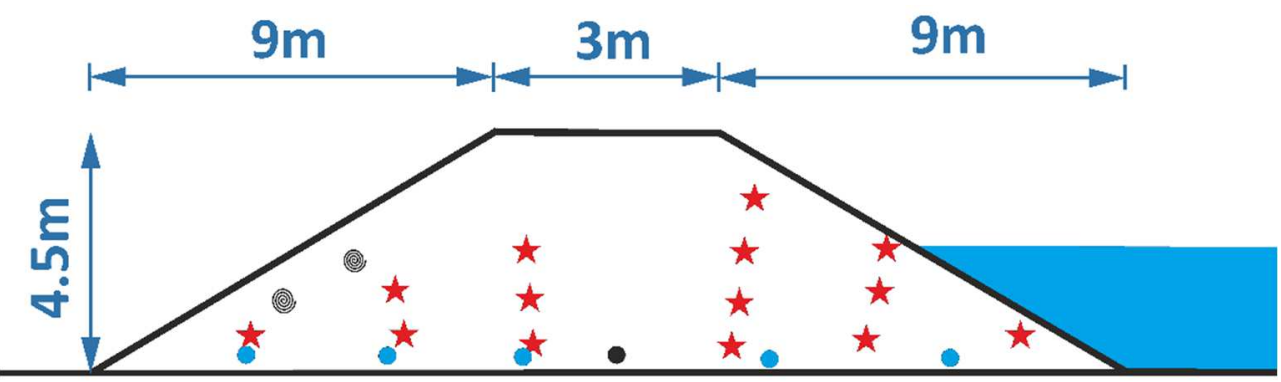

Fig. 2. Location of sensors inside a section in the NW part of the levee. Red stars - Neosentio network (temperature only); dots - Budokop network (blue - temperature \& water pore pressure; black - strain \& temperature); gray dot - optical fibre. The bottoms of the vertical piezometers were located near the blue dots.

\section{Numerical modelling}

Sixteen numerical models were created in Itasca Flac 2D 7.0 software [10-12]. Each model was built using $0.1 \mathrm{~m}$ square cells (fig. 3). Values of geomechanical and hydrogeological properties are presented in table 1. Flood wave modelling was performed assuming the same variable water level for all the 16 numerical models (fig. 4). Material properties, wave shape and temperature came from a real experiment in the ISMOP project. The experiment took place in April 2017. The initial soil temperature decreased linearly from $8^{\circ} \mathrm{C}$ at the bottom edge to $5^{\circ} \mathrm{C}$ at the top edge of the model.

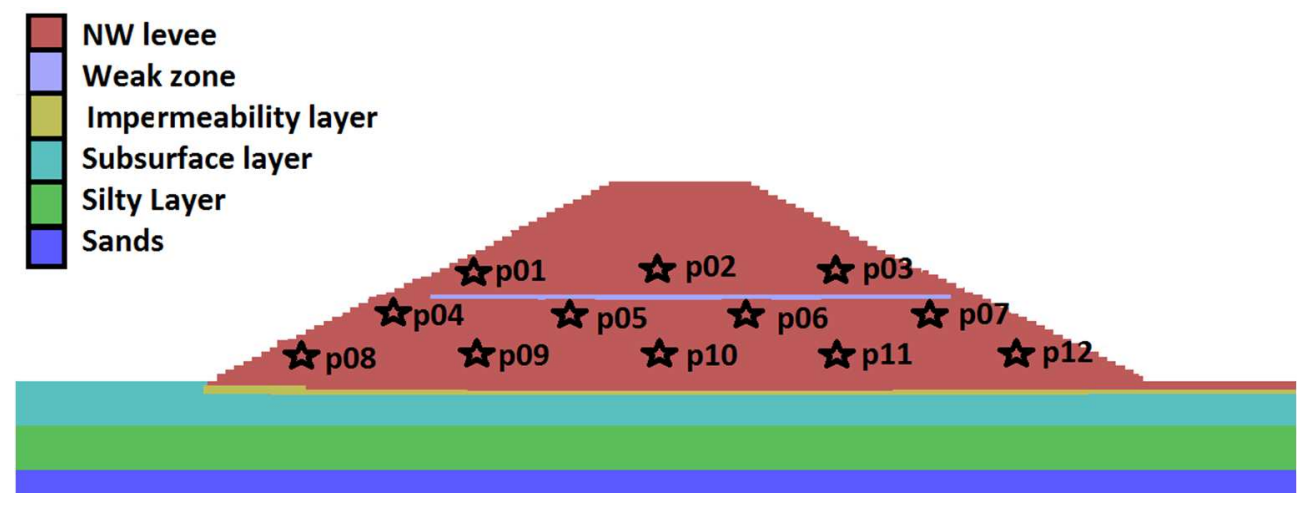

Fig. 3. Physical model used in the calculations. Points p01-p012 were used in fig. 8-9.

Table 1. Geomechanical parameters used in the numerical modelling $[13,14]$.

\begin{tabular}{|l|r|r|r|r|r|}
\hline & $\begin{array}{l}\text { NW levee, } \\
\text { (Weak zone) }\end{array}$ & NE levee & $\begin{array}{l}\text { Subsurface, } \\
\text { (Impermeab } \\
\text { ility layer) }\end{array}$ & Silty & \multicolumn{1}{l|}{ Sands } \\
\hline Density $[\mathrm{kg} / \mathrm{m} 3]$ & 1900 & 1960 & 2100 & 1890 & 1850 \\
\hline Cohesion $[\mathrm{KPa}]$ & 12.50 & 15.43 & 10.30 & 13.70 & 10.00 \\
\hline Friction $\left[{ }^{\circ}\right]$ & 30.04 & 35.20 & 32.90 & 22.50 & 36.20 \\
\hline Bulk Module [MPa] & 8.53 & 7.25 & 7.25 & 16.20 & 36.30 \\
\hline Shear Module [MPa] & 3.27 & 3.35 & 3.43 & 6.63 & 21.80 \\
\hline Porosity [\%] & 37 & 32 & 27 & 40 & 35 \\
\hline Filtration factor $[\mathrm{m} / \mathrm{s}]$ & $\begin{array}{r}1.83^{*} 10^{-5} \\
\text { (vary) }\end{array}$ & $5.24^{*} 10^{-5}$ & $\begin{array}{r}1.52^{*} 10^{-5} \\
\left(1.52^{*} 10^{-12}\right)\end{array}$ & $1.35^{*} 10^{-5}$ & $5.60^{*} 10^{-6}$ \\
\hline
\end{tabular}


Calculations were performed for the various initial and boundary temperature conditions (fig.5):

- real temperature recorded during the experiment

- $\quad$ air temperature plus $5^{\circ} \mathrm{C}$;

- $\quad$ water temperature $=$ air temperature plus $5^{\circ} \mathrm{C}$;

- water temperature plus $5^{\circ} \mathrm{C}$.

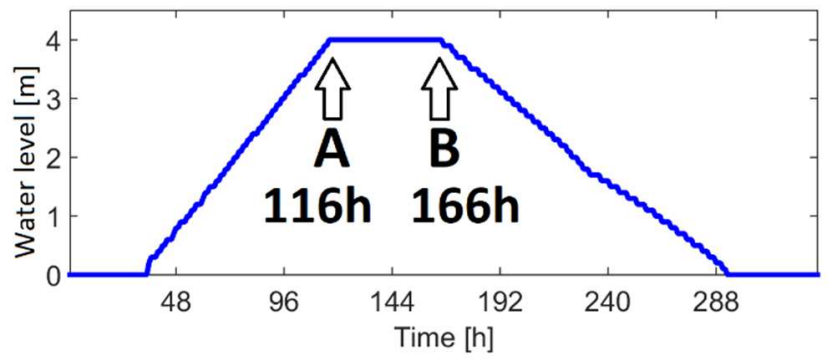

Fig. 4. Water level inside the reservoir used in the numerical modelling. Time points A,B were used for plots in fig. 6-7.

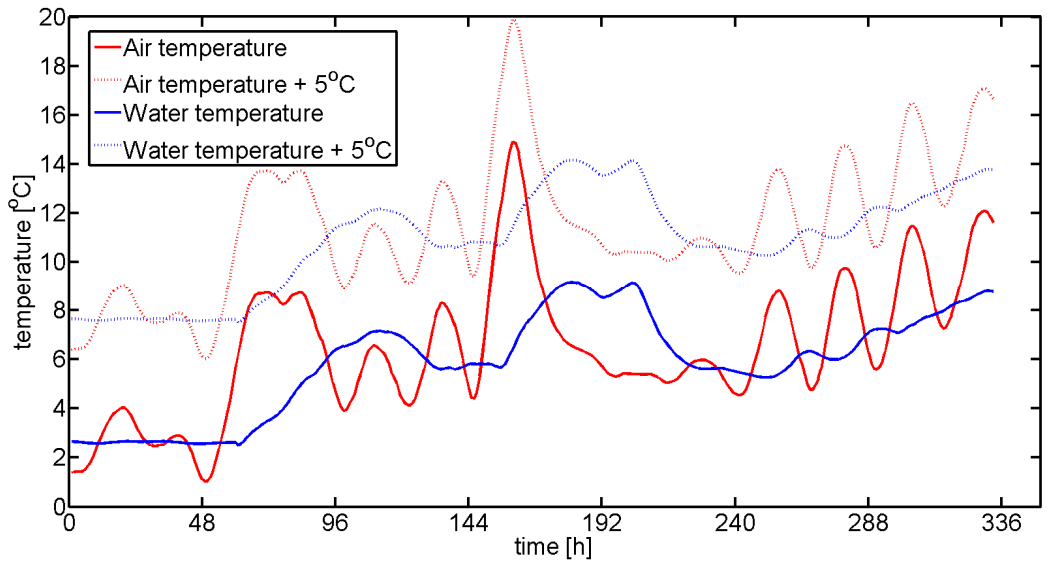

Fig. 5. Water and air temperature used in the numerical modelling (solid line - measured temperature, dots - measured temperature plus $5^{\circ} \mathrm{C}$ ).

The weak zone was represented as a horizontal body $(0.1 \mathrm{~m}$ height and $11.5 \mathrm{~m}$ width $)$. The geomechanical properties of this zone were the same as for the levee. Only permeability and porosity were modified in the numerical model. These modifications are presented in table 2.

Numerical modelling was performed in several steps.

1) Calculation of the equilibrium of the geological medium.

2) Calculation of the equilibrium of the geological medium under levee stress.

3) Iterative calculation of:

a. fluid transport;

b. thermal transport;

c. mechanical equilibrium in a variety of water level and air temperature conditions.

4) Factor of Safety (FoS) calculation.

Iterative calculation were done with $1 \mathrm{~h}$ step. In every step temperature and water level values were fixed on the top edges of the levee model according to fig. 4-5[10]. 
Table 2. Parameters of numerical modellings with calculated FoS value.

\begin{tabular}{|l|l|l|l|l|}
\hline ID & $\begin{array}{l}\text { Ratio of permeability } \\
\text { of weak zone (WZ) } \\
\text { and levee (L) }\end{array}$ & $\begin{array}{l}\text { Increasing porosity of } \\
\text { weak zone due to } \\
\text { levee }\end{array}$ & $\begin{array}{l}\text { Temperature } \\
\text { changes due to } \\
\text { first modelling }\end{array}$ & $\begin{array}{l}\text { Factor of } \\
\text { Safety (FoS) }\end{array}$ \\
\hline 1 & $\mathrm{WZ}=1 \times 1 \times \mathrm{L}$ & ---- & ---- & 2.308 \\
\hline 2 & $\mathrm{WZ}=10 \times \mathrm{L}$ & +0.05 & ---- & 2.314 \\
\hline 3 & $\mathrm{WZ}=100 \times \mathrm{L}$ & +0.05 & ---- & 2.305 \\
\hline 4 & $\mathrm{WZ}=1000 \times \mathrm{L}$ & +0.05 & ---- & 2.267 \\
\hline 5 & $\mathrm{WZ}=1 \times \mathrm{L}$ & ---- & Air $+5^{\circ} \mathrm{C}$ & 2.308 \\
\hline 6 & $\mathrm{WZ}=10 \times \mathrm{L}$ & +0.05 & Air $+5^{\circ} \mathrm{C}$ & 2.314 \\
\hline 7 & $\mathrm{WZ}=100 \times \mathrm{L}$ & +0.05 & Air $+5^{\circ} \mathrm{C}$ & 2.305 \\
\hline 8 & $\mathrm{WZ}=1000 \times \mathrm{L}$ & +0.05 & Air $+5^{\circ} \mathrm{C}$ & 2.267 \\
\hline 9 & $\mathrm{WZ}=1 \times \mathrm{L}$ & ---- & Water $=$ Air $+5^{\circ} \mathrm{C}$ & 2.308 \\
\hline 10 & $\mathrm{WZ}=10 \times \mathrm{L}$ & +0.05 & Water $=$ Air $+5^{\circ} \mathrm{C}$ & 2.311 \\
\hline 11 & $\mathrm{WZ}=100 \times \mathrm{L}$ & +0.05 & Water $=$ Air $+5^{\circ} \mathrm{C}$ & 2.305 \\
\hline 12 & $\mathrm{WZ}=1000 \times \mathrm{L}$ & +0.05 & Water $=$ Air $+5^{\circ} \mathrm{C}$ & 2.267 \\
\hline 13 & $\mathrm{WZ}=1 \times \mathrm{L}$ & +0.05 & Water $+5^{\circ} \mathrm{C}$ & 2.308 \\
\hline 14 & $\mathrm{WZ}=10 \times \mathrm{L}$ & +0.05 & Water $+5^{\circ} \mathrm{C}$ & 2.311 \\
\hline 15 & $\mathrm{WZ}=100 \times \mathrm{L}$ & +0.05 & Water $+5^{\circ} \mathrm{C}$ & 2.305 \\
\hline 16 & $\mathrm{WZ}=1000 \times \mathrm{L}$ & +0.05 & Water $+5^{\circ} \mathrm{C}$ & 2.267 \\
\hline
\end{tabular}

\section{Results}

The numerical experiment was focused on determining the possibility of detecting temperature changes caused by liquid infiltration in the weakened zone. Fig. 6 and fig. 7 present differential maps of temperature values obtained from the numerical modelling.

In the left column, the differences between temperature values modelled for the two ambient temperature boundary conditions are presented. The differences between the temperature values modelled for the two different boundary conditions of the infiltrated water temperature are presented in the right column. The boundary values of the ambient temperature and the temperature of the infiltrating water assumed during numerical modelling are plotted in red and blue in Fig. 5. In both cases the difference between the considered boundary conditions of the ambient and infiltrated liquid temperature was 5 degrees.

Numerical computations were carried out for the various permeability values of the weakened zone. The temperature differences obtained for the base permeability value (table 2) are presented in plots a and e (fig. 6 and 7). In the subsequent plots, the temperature differences obtained for the permeability value of the weakened zone were increased ten times (plots b and f), one hundred times (plots $\mathrm{c}$ and $\mathrm{g}$ ) and one thousand times (plots $\mathrm{d}$ and h).

Temperature changes at several monitoring points are presented in fig. 8 and fig. 9. Temperature changes were visible only for curves with high permeability (at least 100x more than the levee) and are mainly located just under the weak zone. When the soil and water temperatures were similar, there were no significant differences between the curves (fig. 8). The maximum absolute difference between the results of models $1-4$ was more than $1.5^{\circ} \mathrm{C}$ at only one sensor.

When the difference between the soil and water temperatures was bigger (water temperature plus $5^{\circ} \mathrm{C}$, fig. 9), the curves diverge after $100 \mathrm{~h}$ (water level above the weak zone). The maximum absolute difference was as high as $4^{\circ} \mathrm{C}$ at the sensors just under the weak zone. The differences between the curves were mainly visible close to the weak zone in the centre 
of the levee. Small differences in the bottom line of sensors were mainly caused by the existing water residue above the impermeable layer.

\section{Temperature differences}

a)

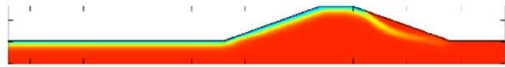

b)

c)

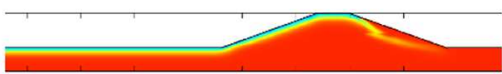

)

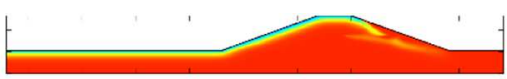

d)

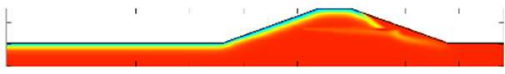

e)

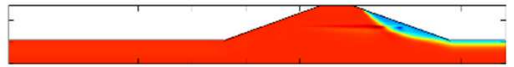

f)

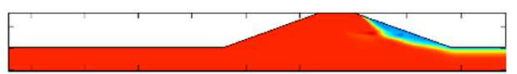

g)

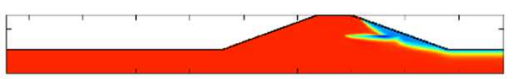

h)

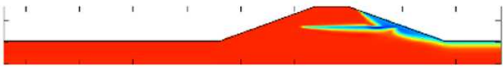

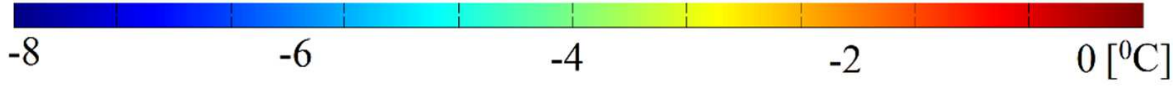

Fig. 6. The differences between the modelled temperature fields for different boundary conditions of the ambient and water temperature obtained for flood wave accumulation (point A in fig. 4). The temperature differences modelled for various ambient and water temperatures are presented in the left and right columns, respectively. Table 2 lists the permeability values used in calculations carried out for the weakened area ( $\mathrm{a}$ and $\mathrm{e}$ ), and for the weakened area with permeability 10 ( $\mathrm{b}$ and $\mathrm{f}$ ), 100 (c and g) and 1000 (e and $\mathrm{h}$ ) times higher.

\section{Temperature differences}

a)

b)

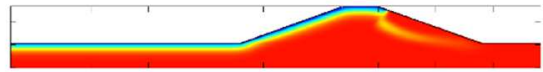

c)
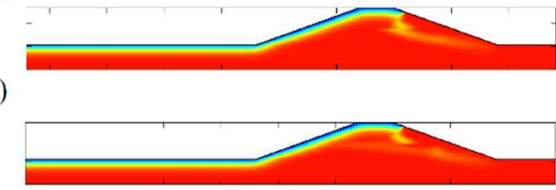

d)

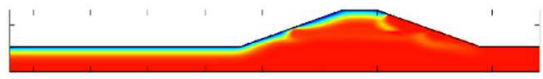

e)

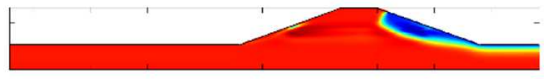

f)

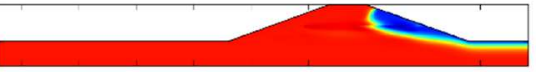

g)

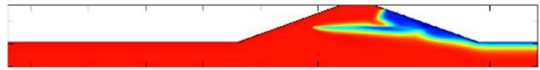

h)

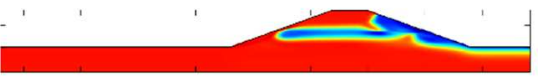

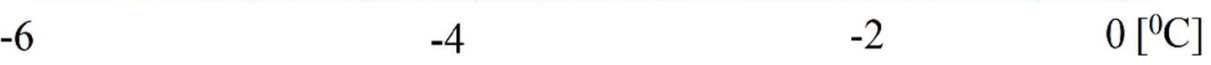

Fig. 7. The differences between modelled temperature fields for different boundary conditions of ambient and water temperature obtained for flood wave accumulation (point B in fig. 4). Temperature differences modelled for various ambient and water temperatures are presented in the left and right columns, respectively. Table 2 lists the permeability values used in calculations carried out for the weakened area ( $\mathrm{a}$ and e), and for the weakened area with permeability 10 (b and f), 100 (c and g) and 1000 (e and h) times higher.

The range of air and water temperatures do not significantly influence the FoS value. Table 2 shows that the FoS value decreases slightly with the increasing permeability of the weak zone, but it was still above 2.2 (stable state). 


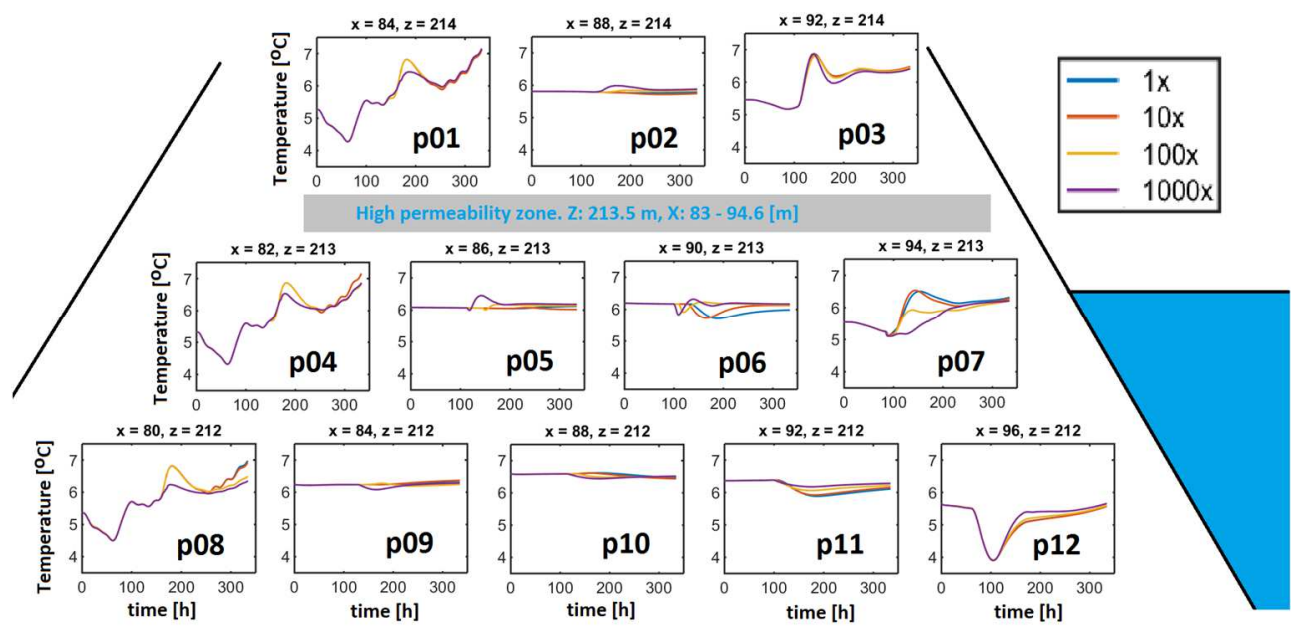

Fig. 8. Temperature changes for model 1-4. Points location were presented on fig. 3. Line 1x $-1000 x$ mean how many times permeability of weak zone are bigger than levee in numerical model.

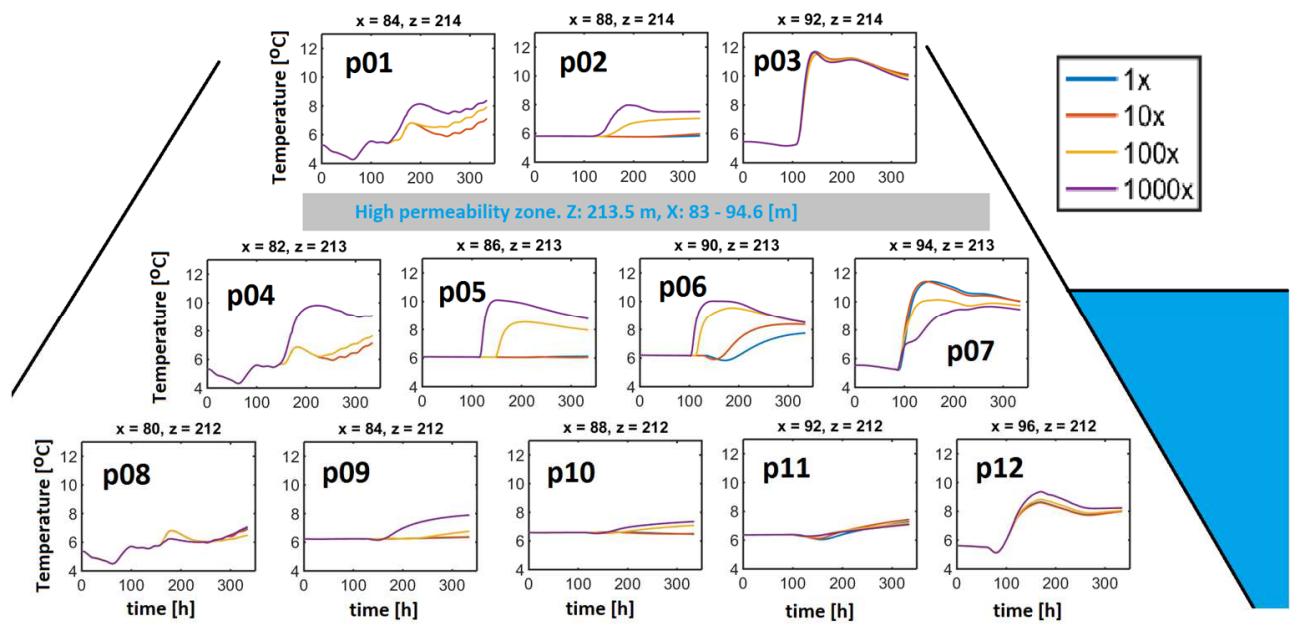

Fig. 9. Temperature changes for model 1-4. Points location were presented on fig. 3. Line $1 x-1000 x$ mean how many times permeability of weak zone are bigger than levee in numerical model.

\section{Conclusions}

Numerical modelling shows that under some conditions it is possible to use temperature sensors to detect high permeability zones in levees. Temperature sensors can be used when a big (at least $5^{\circ} \mathrm{C}$ ) temperature difference between the soil and the water is observed. It was also observed that air temperature exerts a minor influence on sensors close to surface area. Moreover, temperature sensors should be located near potential weak zones. Huge (greater than $4^{\circ} \mathrm{C}$ ) temperature differences were visible for the temperature sensors located $0.5 \mathrm{~m}$ under the weak zone in the centre of the levee. In this area, the effect of air temperature was the smallest and had no influence on the sensor measurements registered during the filtrationrelated processes. 
This work was financed by AGH University of Science and Technology, Faculty of Geology, Geophysics and Environmental Protection, as a part of statutory project no 11.11.140.613. Data used in this work were collected as part of the ISMOP project, sponsored by NCBiR under Grant no. PBS1/B9/18/2013.

\section{References}

1. M. Di Prinzio, M. Bittelli, A. Catellarin, P. Rossi Pisa, J. Appl. Geophys. 71, 2-3, 5361 (2010), doi: 10.1016/j.jappgeo.2010.04.002

2. I.K. Cho, J.Y. Yeom, Geophysics 72, 2, G31-G38 (2007)

3. M.A. Van, C. Zwanenburg, A.R. Koelewijn, H. van Lottum, Proc. 17th Int. Conf. on Soil Mech. and Geot. Eng., Alexandria, Egypt, 2048-2051 (2009) doi: 10.3233/978-160750-031-5-2048

4. V.V. Krzhizhanovskaya, G.S. Shirshov, N.B. Melnikova, R.G. Belleman, F.I. Rusadi, B.J. Broekhuijsen, B.P. Gouldby, J. Lhomme, B. Baliś, M. Bubak, A.L. Pyayt, I.I. Mokhov, A.V. Ozhigin, B. Lang, R.J. Meijer, Procedia Comput. Sci. 4, 106-115 (2011) doi: 10.1016/j.procs.2011.04.011

5. F. Cejka, V. Benes, F. Glac, Z. Boukalova, International Journal of Environmental Impacts 1 (3) 267-278 (2018) doi: 10.2495/EI-V1-N3-267-278

6. M.M. Darrow, Cold Regions Science and Technology 65, 3, 474-487 (2011) doi: 10.1016/j.coldregions.2010.11.00

7. ISMOP - Computer System for Monitoring River Embankments (in Polish: Informatyczny System Monitorowania Obwałowań Przeciwpowodziowych), www.ismop.edu.pl

8. K. Sekuła, A. Borecka, D. Kessler, P. Majerski, Computer Science 18, 4, 357-384 (2017) doi: 10.7494/csci.2017.18.4.2220

9. B. Bukowska-Belniak, M. Dwornik, A. Leśniak, Computer Science 18, 4, 385-397 (2017) doi: 10.7494/csci.2017.18.4.2221

10. M. Dwornik, K. Krawiec, A. Franczyk, A. Leśniak, E3S Web Conf. 7, 03021 (2016) doi: $19.1051 / \mathrm{e} 3$ sconf $/ 20160703021$

11. Itasca Consulting Group Inc., FLAC Fast Lagrangian Analysis of Continua and FLAC/Slope - User's Manual (2011)

12. K. Krawiec, B. Bukowska-Belniak, A. Leśniak, D. Kessler, E3S Web Conf. 7, 03018 (2016) doi: 10.1051/e3sconf/2016

13. J.W. Mościcki, G. Bania, M. Ćwiklik, A. Borecka, Studia Geotech. Mech. 3, 1, 63-70 (2014) doi: 10.2478/sgem-2014-0008

14. J. Stanisz, A. Borecka, Z. Pilecki, R. Kaczmarczyk, E3S Web Conf. 24, 03002, AG 2017 (2017), doi: 10.1051/e3sconf/20172403002 